взаємозв'язків між найменуваннями в латинській та грецькій мові при фрормуванні медичної термінології. При моделюванні ситуацій відбувається активізація інтелектуальної діяльності, а практичне застосування сприяє розширенню лексичного запасу. Для визначення рівня опанування студентами лексики дочільно використовувати елементи сугестивного методу, демонструючи малюнки чи певні дії, вчити студентів послуговуватися словниками синонімів, антонімів, дефініцій та іншими тематичними глосаріями.

Ключові слова: греко-латинська наукова терміносистема, терміноелемент, латинська мова, інтерактивні методи, мотивація, науково-методичне забезпечення.

УДК 796.011.3

Анна Сахненко

Сумський державний педагогічний

університет імені А. С. Макаренка

ORCID ID 0000-0002-8084-3897

DOI 10.24139/2312-5993/2019.05/170-183

\title{
АНАЛІЗ РІВНЯ ПРОФЕСІЙНО-ПРИКЛАДНОЇ ОБІЗНАНОСТІ СТУДЕНТІВ АГРАРНИХ СПЕЦІАЛЬНОСТЕЙ
}

У представленій статmі розглянуто структуру профресійно-прикладної фізичної підготовки студентів закладів вищої освіти. Досліджено рівень професійноприкладної обізнаності студентської молоді аграрних спечіальностей. Установлено, що теоретична складова професійно-прикладної фізичної підготовки значно впливає на формування системи теоретичних і практичних знань студентів, необхідних майбутнім фрахівцям агропромислового комплексу у професійній діяльності й побуті. Аналіз анкетних даних дозволив констатувати недостатній рівень знань майбутніх фахівців агропромислового комплексу в галузі фрізичної культури, спорту, здорового способу життя і професійно-прикладної фрізичної підготовки.

Ключові слова: профресійно-прикладна обізнаність, фізичне виховання, рівень, компонент, обсяг знань, студенти аграрних спеціальностей.

Постановка проблеми. На сучасному етапі свого розвитку промисловість нашої країни відчуває потребу в освічених, висококваліфікованих фахівцях, які володіють фундаментальними знаннями, професійними вміннями та навичками, досвідом творчого вирішення нових актуальних проблем та здатністю до самореалізації навичок і вмінь у різних сферах професійної діяльності. Основною складовою економіки України є агропромисловий комплекс, що поєднує в собі виробництво сільськогосподарської продукції, ії сільськогосподарську переробку й матеріально-технічне обслуговування села (Сахненко та Коломієць, 2018).

Однак, аграрна промисловість нашої країни останнім часом гостро відчуває брак кваліфікованих спеціалістів. Однією з головних причин 
виникнення проблеми є низький рівень професійно-прикладної фізичної підготовленості випускників закладів вищої освіти аграрного профілю (Сахненко, 2018).

За свідченнями фахівців, значна кількість сучасних випускників закладів вищої освіти фізично неспроможні задовольнити сучасні вимоги ринку праці (Присяжнюк, 2010, Раєвський, 2000). У такому контексті важливого значення для підготовки майбутнього фахівця в закладі вищої освіти набуває система фізичного виховання, зокрема її професійно-прикладна складова. Професійна спрямованість аграрної вищої освіти обумовлює необхідність у процесі формування особистості майбутнього фахівця. Особливу увагу звертали на розвиток його професійних якостей, на професійне виховання Т. Г. Приставський, О. Л. Ковбан, А. М. Бабич, М. М. Стахів (Приставський та ін., 2013, с. 419).

У навчальній програмі з фізичного виховання наголошується, що одним із головних критеріїв ефективності фізичного виховання випускників $€$ знання основ ППФП й уміння їх застосовувати на практиці (Божик, 2013, с. 33).

Професійно орієнтований напрям організації фізичного виховання створює передумови для успішного оволодіння професійними навичками і практичними знаннями, досягнення належного рівня фізичної й функціональної підготовленості організму студента, допомагає скоротити термін адаптації до умов праці та подовжити професійне довголіття майбутнього фахівця агропромислового комплексу (Пилипей, 2011). Науковці зазначають, що на підставі базової професійної моделі фахівця розробляється програма ППФП майбутнього спеціаліста, яка включає засоби і методи навчання, методи оцінки фізичних, психологічних і психофізіологічних якостей особистості, параметри професійної надійності, фізичного здоров'я і прогноз професійного довголіття (Маляр та Будний, 2009).

Не менш важливе значення для підготовки спеціаліста має когнітивний компонент професійно-прикладної фізичної підготовки, що забезпечує формування системи загальнотеоретичних, методичних і професійно-прикладних знань із метою їх подальшого використання у професійній діяльності й побуті. Однак, у працях науковців недостатньо висвітлено рівень професійно-прикладної обізнаності студентства. Це і зумовило вибір теми нашого дослідження.

Роботу виконано відповідно до зведеного плану науково-дослідної роботи кафедри теорії і методики фізичної культури Сумського державного педагогічного університету імені А. С. Макаренка на 2016-2020 рр. за темою «Теоретичні і методичні основи фізкультурної освіти різних груп населення» (номер державної реєстрації 0116U000900). 
Аналіз актуальних досліджень. Професійна підготовка студентів повинна бути спрямована, передусім, на оволодіння визначеним обсягом теоретичних знань, практичних умінь і навичок, на підтримку необхідного стану здоров'я, а також на цілеспрямований розвиток професійної працездатності, пов'язаної 3 достатнім розвитком фізичних та психофізіологічних якостей (Семенів, 2012). Особливостям професійноприкладної фізичної підготовки студентів аграрних вищих навчальних закладів присвятили наукові праці В.Ільїніч, Ю. Позднякова, М. Хома, Н. Сторчевой. У роботах Н. Безгодової, Н. Бібік, В. Введенського, Т. Гороховської, М. Лісового, В. Момота, А. Хуторського визначено критерії і проаналізовано рівні сформованості показників професійно-прикладної фізичної підготовки студентів закладів вищої освіти.

Я. Зорій інтерпретує професійно-прикладну фізичну підготовку як складний процес цілеспрямованого педагогічного впливу на фізичні, психічні, психофізіологічні та морфофункціональні показники розвитку організму, у результаті якого професійні знання та навички майбутніх фахівців перетворюються в параметри їх готовності до виконання професійних обов'язків (Зорій, 2013, с. 23-24).

Б. Семенів виділяє два блоки змісту професійно орієнтованої фізичної підготовки студентів факультету харчових технологій фізкультурну освіту (теоретичний блок) і професійно-прикладну фізичну підготовку (практичний блок) (Семенів, 2012, с. 193).

М. Божик критерієм ефективності методичного компоненту системи професійно-прикладної фізичної підготовки вчителів вважає рівень їх професійно-прикладної методичної готовності.

Р. Раєвський структурними компонентами ППФП студентів енергетичних спеціальностей вважає методичну, практичну й теоретичну підготовку. Він виокремлює такі завдання теоретичної підготовки:

- продовження мотивації студентів на здійснення ППФП у період навчання у ЗВО на навчальних заняттях і в позанавчальний час;

- подальше оволодіння системою знань, необхідних для практичної реалізації індивідуальної ППФП до майбутньої обраної професійної діяльності в енергетичному комплексі на етапі вузівської освіти (Раєвський та Канішевський, 2008).

Незважаючи на значну кількість сучасних досліджень у сфері професійно-прикладної фізичної підготовки студентів закладів вищої освіти (Петренко, 2018; Карабанов, 2016; Хоменко, 2017 та ін.), доводиться констатувати, що в науковій літературі відсутні праці, у яких представлено 
аналіз рівня професійно-прикладної обізнаності студентів аграрних спеціальностей нашої країни.

Мета статті - дослідити рівень професійно-прикладної обізнаності студентів аграрних спеціальностей.

Методи дослідження: теоретичний аналіз літературних джерел, анкетування, методи математичної статистики.

Виклад основного матеріалу. У дослідженні брали участь студенти I-III курсів аграрних спеціальностей Сумського національного аграрного університету (n=652), Харківського національного технічного університету сільського господарства ім. Петра Василенка (n=431) та Глухівського агротехнічного інституту ім. С. А. Ковпака $(n=108)$ у загальній кількості 1201 особа.

3 метою визначення рівня професійно-прикладної обізнаності студентів-аграріїв нами було проведено анкетування. Анкета містила 5 блоків питань, що об'єднуються за такими ознаками:

1. Загально-теоретичний - виявлення обсягу знань стосовно фізичних якостей та понять «фізична культура» $\mathrm{i}$ «фізичне виховання».

2. Методичний - виявлення обсягу знань з методики розвитку фізичних якостей.

3. Аксіологічний - виявлення обсягу знань стосовно рекреаційних заходів і самостійних занять фізичними вправами; умов і причин, що спонукають до здійснення рухової активності.

4. Прогностичний - визначення обсягу знань про значення занять фізичною культурою для майбутньої самореалізації фахівця за обраною спеціальністю, уявлень студентства стосовно шляхів оптимізації системи фізичного виховання в закладі вищої освіти аграрного профілю.

5. Професійно-прикладний - виявлення обсягу знань стосовно поняття «професійно-прикладна фізична підготовка», професійноважливих фізичних якостей, основних правил техніки безпеки та першої медичної допомоги в обраній професійній діяльності.

Опрацювання результатів анкетування здійснювалося за кількісними та якісними оцінками відповідей. Кількісна оцінка передбачає оцінювання наданих відповідей за шкалою. Обсяг знань студента, виявлений у кожному блоці, оцінювався кількістю балів від 0 до 2.

Рівень професійно-прикладної обізнаності майбутніх фахівців аграрної промисловості визначався за сумою балів, отриманих досліджуваним у кожному блоці питань. Отримана кількість балів співвідноситься з якісною оцінкою - відповідним рівнем професійно-прикладної обізнаності й передбачає наявність у досліджуваних певного рівня теоретичних знань і уявлень. 
Аналіз отриманих відповідей дозволяє зробити висновок про рівень обізнаності майбутніх аграріїв щодо методів самоконтролю у фізичному вихованні. 36,8 \% студентів не мали труднощів з відповіддю на питання, 13,6 \% з них змогли назвати два і більше методів. Найчастіше називалися такі методи: вимірювання ЧСС, вимірювання тиску, вимірювання температури тіла. Зауважимо, що 22,7\% опитаних не змогли самостійно визначити свою чСС.

Значні труднощі з відповідями виникали на питання стосовно визначення фізичних якостей («сила - це», «координаційні здібності - це», та ін.), методики їх розвитку та визначень понять «фізична культура» i «фізичне виховання». У 53,1\% студентів фізична культура асоціюється зі спортом; у 13,6\% - із заняттями фізичними вправами; 9,7\% визначили фізичну культуру як загальну культуру людства; 23,6 \% опитаних не змогли визначитися з відповіддю на поставлене питання.

Поняття «фізичне виховання» 47,4\% респондентів визначили як комплекс вправ, яким навчають на практичних заняттях; 21,8 \% опитаних вважають фізичне виховання вихованням студентів на заняттях; у 19,1\% фізичне виховання асоціюється з фізичною культурою або ії різновидом; 11,7 \% опитаних мали труднощі з відповіддю.

Відповіді на питання стосовно визначення фізичних якостей відрізнялися варіативністю. Ми виділили такі варіанти визначень, які найчастіше зустрічалися серед відповідей опитуваних:

- сила - це: «здатність піднімати обтяження», «здатність виконувати важку роботу», «здатність переносити вантаж на велику відстань», «здатність виконувати силові вправи»;

- витривалість - це: «здатність довго бігати», «здатність виконувати роботу тривалий час», «здатність бігати на довгі дистанції» та ін.;

- спритність - це: «здатність виконувати складну роботу», «здатність швидко реагувати», «здатність орієнтуватись у різних ситуаціях», «здатність переносити дрібні предмети» та ін.;

- гнучкість - це: «здатність нахилятися», «здатність розтягувати м'язи», «здатність виконувати гімнастичні вправи» та ін.;

- швидкісні здібності - це: «швидкість», «здатність швидко бігати», «здатність бігати на короткі дистанції», «здатність швидко виконувати роботу» та ін.;

- координаційні здібності - це: «орієнтація у просторі», «здатність швидко реагувати», «здатність тримати рівновагу» та ін. 
Проаналізувавши відповіді на питання загальнотеоретичного блоку, можемо зробити висновки щодо рівня обізнаності студентства за даним показником. 93,8 \% опитаних не змогли відповісти на питання зазначеного блоку, отримані відповіді оцінені в 0 балів; 6,2 \% респондентів, формулюючи визначення своїми словами, не змогли передати сутності і змісту понять, рівень обсягу знань за даним показником оцінено в 1 бал. Відповіді на питання методичного характеру дуже різнились і не мали чіткого оформлення. Нами було зафіксовано такі варіанти відповідей на питання стосовно методики розвитку фізичних якостей (табл. 1).

Таблиця 1

Уявлення студентів аграрних спеціальностей стосовно методики розвитку фізичних якостей

\begin{tabular}{|l|l|}
\hline \multicolumn{1}{|c|}{ Фізичні якості } & \multicolumn{1}{|c|}{ Методика розвитку } \\
\hline Сила & $\begin{array}{l}\text { «піднімати обтяження», «підтягуватись на перекладині», } \\
\text { «качатись», «бігати» та ін. }\end{array}$ \\
\hline Витривалість & $\begin{array}{l}\text { «довго працювати», «багато займатись», «ходити на } \\
\text { фізкультуру», «довго бігати»та ін. }\end{array}$ \\
\hline Спритність & «багато бігати», «займатись» та ін. \\
\hline Гнучкість & $\begin{array}{l}\text { «виконувати вправи на розтягнення», «нахилятись», «торкатись } \\
\text { носків, не згинаючи ноги у колінах», «тренуватись», «займатися } \\
\text { гімнастикою»та ін. }\end{array}$ \\
\hline $\begin{array}{l}\text { Швидкісні } \\
\text { здібності }\end{array}$ & $\begin{array}{l}\text { «багато бігати», «бігати на короткі дистанції», «тренуватися», } \\
\text { «брати участь уммаганнях» та ін. }\end{array}$ \\
\hline $\begin{array}{l}\text { Координаційні } \\
\text { здібності }\end{array}$ & $\begin{array}{l}\text { «вчитися тримати рівновагу на одній нозі», «виконувати складні } \\
\text { вправи», «займатися спортивними іграми» та ін. }\end{array}$ \\
\hline
\end{tabular}

Підсумовуючи вищесказане, зауважимо , що 87,4 \% респондентів мали труднощі 3 відповідями на питання методичного блоку; 10,8 \% опитаних не змогли дати повних і змістовних відповідей щодо методики розвитку фізичних якостей; 1,8 \% студентів надали відповіді загального характеру, не вказавши особливостей методик та дозування навантаження. Здійснивши кількісну оцінку отриманих результатів, можемо констатувати, що 87,4 \% студентів отримують 0 балів; відповіді 12,6 \% досліджуваних оцінено в 1 бал.

Важливість рекреаційних заходів для зміцнення та збереження здоров'я й запобігання розумового перевантаження розуміють 35,7 \% майбутніх аграріїв: 9,6 \% студентів вказали на захоплення туризмом і туристичними походами; 8,8 \% здійснюють велосипедні та піші прогулянки; 17,3 \% віддають перевагу спортивним та рухливим іграм на свіжому повітрі. 31,9 \% студентства відзначили брак вільного часу для активного відпочинку; 32,4 \% досліджуваних не мають бажання здійснювати рухову активність у вільний час. 
Визначаючи умови, що спонукають студентів до здійснення рухової активності, ми отримали такі результати (табл. 2).

Таблиця 2

Умови, що мотивують студентів аграрних спеціальностей до занять фізичною культурою

\begin{tabular}{|c|c|c|c|}
\hline \multirow{2}{*}{$\begin{array}{c}\text { Групи змістовних } \\
\text { рангів }\end{array}$} & \multicolumn{3}{|c|}{ Курси } \\
\hline & 1 & II & III \\
\hline Наявність бажання виконувати фізичні вправи & $38,4 \%$ & $29,3 \%$ & $27,6 \%$ \\
\hline $\begin{array}{l}\text { Використання новітніх засобів, методів та } \\
\text { методичних прийомів на заняттях із фізичного } \\
\text { виховання }\end{array}$ & $13,1 \%$ & $19,7 \%$ & $26,1 \%$ \\
\hline $\begin{array}{l}\text { Наявність гарного тренера, викладача, } \\
\text { інструктора }\end{array}$ & $10,6 \%$ & $7,8 \%$ & $4,3 \%$ \\
\hline Наявність часу & $7,9 \%$ & $10,8 \%$ & $16,1 \%$ \\
\hline Гарне самопочуття & $8,1 \%$ & $11,1 \%$ & $12,6 \%$ \\
\hline Наявність інвентарю та умов & $10,9 \%$ & $12,4 \%$ & $4,8 \%$ \\
\hline Інші чинники & $4,7 \%$ & $3,2 \%$ & $4,1 \%$ \\
\hline Складно відповісти & $6,3 \%$ & $5,7 \%$ & $4,4 \%$ \\
\hline
\end{tabular}

Як бачимо, головною причиною займатисья фізичною культурою 38,4 \% першокурсників вважають наявність бажання здійснювати рухову активність. Серед студентів II та III курсів дану умову вказали 29,3 \% і 27,6 \% відповідно. 13,1 \% першокурсників, 19,7 \% другокурсників і 26,1\% студентів III курсів відзначають важливість використання новітніх засобів, методів та методичних прийомів на заняттях із фізичного виховання. За відсутності гарного тренера, інструктора, викладача не бажають займатися 10,6 \%, 7,8 \% і 4,3 \% студентів I, II і III курсів відповідно. Найбільший відсоток студентів, яким заважає займатися брак часу, виявлено серед респондентів, що навчаються на III курсах; 10,8 \% - серед другокурсників і 7,9 \% - серед студентів I курсів. Середній відсоток опитаних, що головною умовою для занять фізичною культурою вважають наявність гарного самопочуття та здоров'я, коливається в межах 8-12 \%. Наявність інвентарю та умов визначили важливою умовою 10,9 \% першокурсників і 12,4 \% та 4,8 \% студентів II та III курсів відповідно.

За результатами анкетування в аксіологічному блоці питань було визначено кількісні оцінки знань досліджуваних за даним показником: 0 балів - 82,1\%; 1 бал - 13,3\%; 2 бали - 4,6\%.

При виборі форм занять з фізичного виховання 18,1 \% опитаних зупинили свій вибір на практичних заняттях; секційні заняття як пріоритетну форму обрали 13,9 \%; лекційні заняття - 2,3 \%. У 65,7\% респондентів виникли труднощі з відповіддю на зазначене питання. 
Аналіз отриманих відповідей дозволяє констатувати, що 83,4\% анкетованих студентів не задоволені умовами, у яких проходять заняття 3 фізичного виховання: 28,7 \% майбутніх аграріїв вважають головною умовою проведення занять наявність чистого та добре освітленого приміщення спортивного залу; 16,4 \% зазначили, що хотіли би більше займатися на свіжому повітрі; 38,3 \% опитаних бажали б займатись у тренажерному залі 3 гарним технічним оснащенням. 1,3 \% студентства цілком влаштовують умови занять; у 15,3 \% досліджуваних виникли труднощі з відповіддю на поставлене питання. Слід відмітити, що пріоритетними шляхами оптимізації процесу фізичного виховання у ЗВО аграрного профілю студенти вважають:

- зміни змісту навчальної програми (23,2 \%);

- зміни форм занять із фізичного виховання $(9,4 \%)$;

- зміни технічного оснащення та умов проведення занять (16,9%).

50,5 \% досліджуваного контингенту не змогли дати відповідь на поставлене питання.

Кількісна оцінка відповідей студентів на питання прогностичного блоку становить: 0 балів - 72,6 \% студентства; 1 бал - 25,8 \%; 2 бали - 1,6 \%.

Дані, отримані в результаті аналізу відповідей професійноприкладного блоку, показали, що більшість студентів I-III курсів мають слабкі уявлення стосовно змісту й сутності професійно-прикладної фізичної підготовки взагалі та її особливостей для природничо-аграрної групи спеціальностей. Уявлення студентів стосовно визначення поняття «професійно-прикладна фізична підготовка» представлені в таблиці 3.

0,6 \% студентів першого, 1,3 \% - другого, і 2,6 \% - третього курсів розглядають ППФП як навчальний процес. У межах 5-14 \% коливається кількість відповідей респондентів, у яких професійно-прикладна фізична підготовка асоціюється з комплексом фізичних вправ та заходів, спрямованих на краще оволодіння майбутньою професією. У ППФП вбачають сукупність фізичних якостей майбутнього працівника АПК - 7,9 \% опитаних першокурсників, 5,8 \% - другокурсників, та 9,1 \% студентської молоді третіх курсів. Професійно-прикладній фізичній підготовці, як комплексу теоретичних знань, важливих для обраного напрямку професії віддали перевагу близько 9 \% студентів I та II курсів. 13,7 \% студентів III курсів вважають ППФП теоретичною підготовкою майбутнього фахівця. Уявленням про професійноприкладну фізичну підготовку, як спеціально спрямоване використання засобів фізичного виховання для підготовки майбутнього фахівця до особливостей професійної діяльності, надали перевагу 0,9 \% - студентів першого, 9,1 \% - другого і 4,3 \% - третього курсів. 
Таблиця 3

Уявлення студентів аграрних спеціальностей стосовно сутності поняття «професійно-прикладна фізична підготовка»

\begin{tabular}{|c|c|c|c|}
\hline \multirow{2}{*}{$\begin{array}{c}\text { Групи змістовних } \\
\text { рангів }\end{array}$} & \multicolumn{3}{|c|}{ Курси } \\
\hline & 1 & II & III \\
\hline Уявлення про ППФП як навчальний процес & $0,6 \%$ & $1,3 \%$ & $2,6 \%$ \\
\hline $\begin{array}{l}\text { Уявлення про ППФП як комплекс фізичних } \\
\text { вправ та заходів, спрямований на краще } \\
\text { оволодіння майбутньою професією }\end{array}$ & $5,6 \%$ & $9,8 \%$ & $14,6 \%$ \\
\hline $\begin{array}{l}\text { Уявлення про ППФП як сукупність фізичних } \\
\text { якостей майбутнього працівника АПК }\end{array}$ & $7,9 \%$ & $5,8 \%$ & $9,1 \%$ \\
\hline $\begin{array}{l}\text { Уявлення про ППФП як комплекс теоретичних } \\
\text { знань, важливих для обраного напрямку } \\
\text { професії }\end{array}$ & $8,1 \%$ & $9,3 \%$ & $13,7 \%$ \\
\hline $\begin{array}{llrr}\text { Уявлення } & \text { про ППФП як } & \text { спеціально } \\
\text { спрямоване використання засобів фізичного } \\
\text { виховання для підготовки } \\
\begin{array}{l}\text { фахівця дайбутнього } \\
\text { діяльності }\end{array}\end{array}$ & $0,9 \%$ & $9,1 \%$ & $4,3 \%$ \\
\hline Інші уявлення & $5.6 \%$ & $1.2 \%$ & $5.9 \%$ \\
\hline Складно відповісти & $71.3 \%$ & $63.5 \%$ & $49.8 \%$ \\
\hline
\end{tabular}

Слід зауважити, що кількість студентів, яким було складно відповісти на зазначене питання, становить більше 50 \% досліджуваного контингенту. Безсумнівно, отримані результати є показником низького рівня обізнаності значної частини студентства стосовно професійно-прикладної фізичної підготовки. Позитивним моментом є зменшення кількості студентів, що мали труднощі з відповіддю з I по III курс майже вдвічі.

Серед професійно важливих якостей студентами I-III курсів було виділено такі: сила - 56,3 \%, витривалість - 67,9 \%, спритність - 21,6 \%, координаційні здібності - 35,8 \%, швидкісні здібності - 38,4 \% гнучкість $12,7 \%$ (рис. 1$)$.

Труднощі з відповіддю на питання щодо професійно важливих фізичних якостей виникли у близько 14,7 \% респондентів. Слід зазначити, що найбільшу частину з них - 72,4 \% - становили першокурсники.

48,1 \% студентів вважають, що для успішного оволодіння професією необхідно ретельно вивчати спеціальні теоретичні дисципліни з обраного напряму. Важливу роль занять фізичним вихованням та спортом визначили 15,6 \% респондентів, 4,8 \% з них вважають, що фізична підготовка повинна мати професійне спрямування та враховувати особливості майбутньої професії. 36,3 \% студентства складно було визначитися з відповідями на питання стосовно ППФП. 


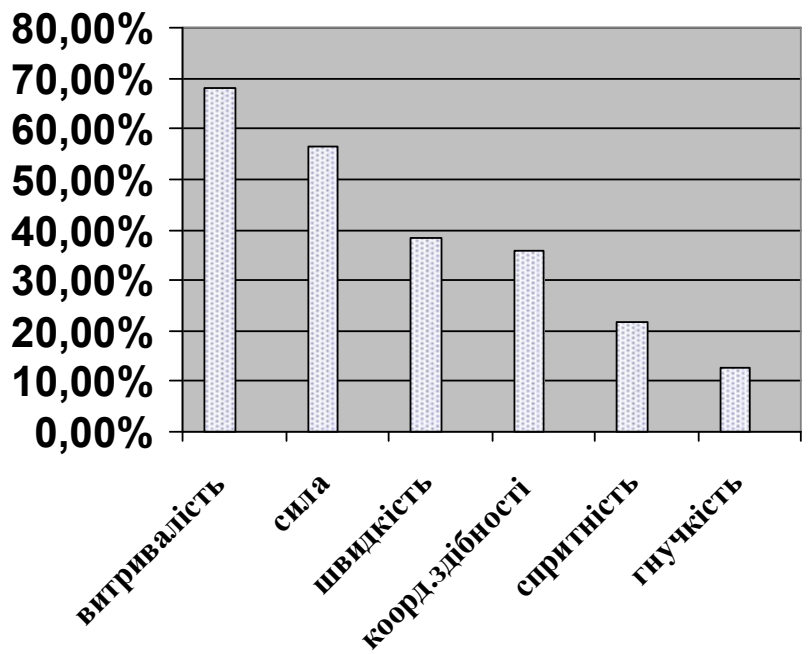

Рис.1 Уявлення студентів аграрних спеціальностей стосовно ступеня професійної важливості фізичних якостей за обраною спеціальністю

Проаналізувавши відповіді на питання професійно-прикладного блоку, можемо констатувати наявність незадовільного рівня обізнаності у 85,3 \% респондентів, їх відповіді було оцінено у 0 балів. $12,5 \%$ досліджуваних змогли відповісти на поставлені питання, однак їх відповіді не були чітко сформульовані і не повністю розкривали зміст та особливості понять, представлених у даному блоці, їх відповідям була надана оцінка 1 бал. 2 бали отримали 2,2 \% студентства, які змогли чітко і змістовно відповісти на питання, виявили обізнаність стосовно особливостей своєї майбутньої професії і підготовки до умов праці.

Аналіз результатів дослідження дозволив визначити загальний рівень професійно-прикладної обізнаності студентів аграрних спеціальностей (рис. 2).
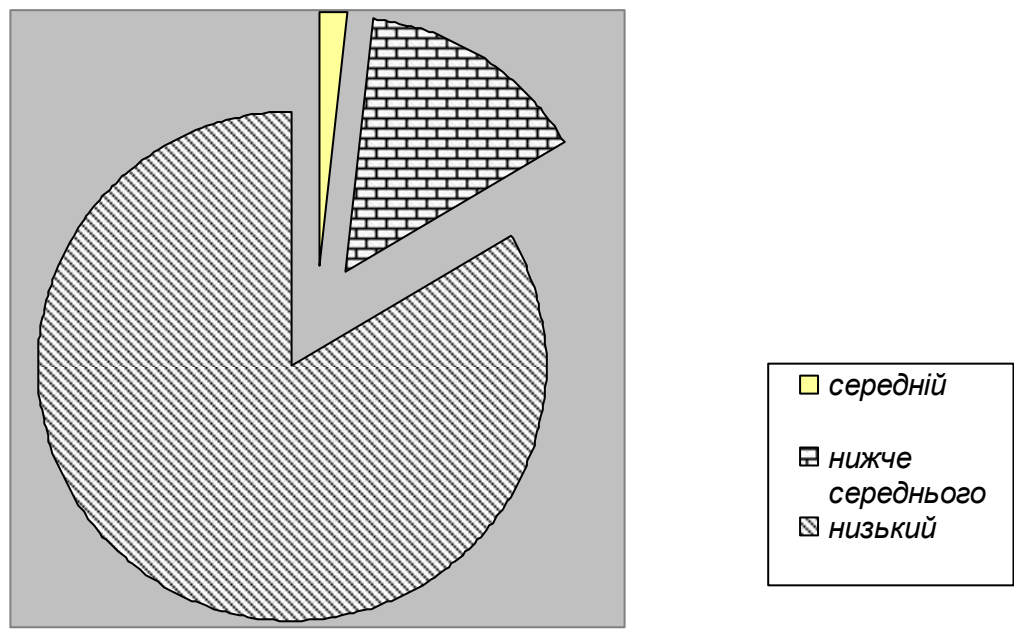

Рис. 2. Рівень професійно-прикладної обізнаності студентів аграрних спеціальностей 
у 1,6 \% студентів виявлено середній рівень професійно-прикладної обізнаності; у 14,8 \% визначено рівень, нижчий за середній; 83,6 \% досліджуваних демонструють низький рівень.

Висновки. У результаті проведеного анкетування можна констатувати, що більшість майбутніх аграріїв мають низький рівень професійно-прикладної обізнаності. На це вказує високий відсоток респондентів, які мали труднощі з наданням відповідей теоретичного, методичного, професійно-прикладного та інших напрямів. Значна частка відповідей студентів виявилася далекою від загальноприйнятих визначень понять. Незначним є відсоток відповідей, які би були чітко оформлені й розкривали повністю зміст визначень, запропонованих в анкетах.

Низький рівень професійно-прикладної обізнаності зафіксовано у 83,6\% респондентів; рівень, нижчий за середній - у 14,8 \%; середній у 1,6 \%. Зазначимо, що результатів, які відповідають вищому за середній та високому рівням професійно-прикладної обізнаності, серед студентства виявлено не було.

Напрями подальших досліджень ми вбачаємо в розробці та експериментальній перевірці ефективності професійно-орієнтованої моделі організації фізичного виховання студентів аграрних спеціальностей.

\section{ЛІТЕРАТУРА}

Божик, М. (2013). Професійно-прикладна фізична підготовка як ефективна умова формування готовності майбутніх учителів-предметників до професійної діяльності. Фізичне виховання, спорт і культура здоров'я у сучасному суспільстві, 1 (21), 32-35 (Bozhyk, M. (2013). Professional-applied physical training as an effective condition for forming the readiness of future teachers for professional activity. Physical education, sports and health culture in modern society, 1 (21), 32-35).

Зорій, Я. Б. (2013). Підвищення професійно прикладної дієвості фізичного виховання у ВН3 через формування у студентів мотивації до самостійних занять. Фізична культура і спорт у навчальних закладах східноєвропейських країн, (сс. 22-25). Чернівці (Zorii, Yа. B. (2013). Enhancement of the professionally applied efficiency of physical education in higher education institutions through the formation of students' motivation to study independently. Physical culture and sports in education institutions of Eastern European countries, (pp. 22-25). Chernivtsi).

Маляр, Е. І., Будний, В. Є. (2009). Професійно-прикладна фізична підготовка студентів у системі вищої професійної освіти. Педагогіка, психологія та медико-біологічні проблеми фрізичного виховання і спорту, 12, 120-123 (Maliar, E. I., Budnyi, V. Ye. (2009). Professional-applied physical training of students in the system of higher professional education. Pedagogy, psychology and medical-biological problems of physical education and sports, 12, 120-123).

Петренко, О. (2018). Характеристиа мотивів та рухових уподобань студентів до занять 3 фізичного виховання. Педагогічні науки: теорія, історія, інноваційні технології, 2 (76), 175-185 (Petrenko, O. (2018). Characteristics of the motives and motor preferences of the students for physical education classes. Pedagogical sciences: theory, history, innovative technologies, 2 (76), 175-185). 
Пилипей Л. П. (2011). Теоретико-методичні основи професійно-прикладної фрізичної підготовки студентів вищих навчальних закладів (автореф. дис. ... докт. наук з фіз. вих. і спорту: 24.00.02). Київ (Pуlypei, L. Р. (2011). Theoretical-methodological bases of professional-applied physical training of students of higher education institutions (DSc thesis abstract). Kyiv).

Приставський, Т. Г., Ковбан, О. Л., Бабич, А. М., Стахів, М. М. (2013). ППФП та її місце в системі фізичного виховання в аграрних вищих навчальних закладах. Науковий вісник ЛНУВМБТ імені С. 3. Гжицького, Том 15, № 3 (57), 4. 4, 419-422 (Prystavskyi, T. H., Kovban, O. L., Babych, A. M., Stakhiv, M. M. (2013). PAPT and its place in the system of physical education in agrarian higher educational establishments. Scientific bulletin of LNUWMBT named after S. Z. Gzhitsky, Vol. 15, No. 3 (57), Part 4, 419-422).

Присяжнюк, С. І. (2010). Біологічний вік та здоров'я студентської молоді. К.: Центр навчальної літератури. Київ (Prysiazhniuk, S. І. (2010). Biological age and health of student youth. K.: Center for Educational Literature. Kyiv).

Раевский, Р. Т., Канішевский, С. М. (2008). Профессионально-прикладная физическая подготовка. О.: Наука и техника (Raievsky, R. Т., Kanishevskyi, S. М. (2008). Professional-applied physical training. O.: Science and technology).

Сахненко, А. В. (2018). Аналіз структури світогляду студентів аграрних спеціальностей у сфері фізичної культури і здоров'я. Вісник Чернігівського національного педагогічного університету імені Т.Г. Шевченка. Педагогічні науки, 152, 72-75 (Sakhnenko, A. V. (2018). Analysis of the structure of the outlook of students of agricultural specialties in the field of physical culture and health. Bulletin of Taras Shevchenko Chernigiv National Pedagogical University. Pedagogical sciences, 152, 72-75).

Сахненко, А. В., Коломієць, А. Я. (2018). Завдання професійно-орієнтованої фізичної підготовки кваліфікованих спеціалістів агропромислового комплексу. Спортивний вісник Придніпров'я. Фізичне виховання та спорт, 2, 130-134 (Sakhnenko, A. V., Kolomiiets, A. Ya. (2018). The task of professional-oriented physical training of skilled specialists in the agro-industrial complex. Sports bulletin of Prydnistrovia. Physical Education and Sports, 2, 130-134).

Сэмэнив, Б. С. (2014). Определение структуры профессиональной подготовки студентов-технологов пищевой промышленности для использования оптимальных режимов физической тренировки. Науковий часопис Національного педагогічного університету імені М. П. Драгоманова. Серія 15: Науково-педагогічні проблеми фізичної культури (фізична культура і спорт), 3 (46), 87-92 (Semeniv, B. S. (2014). Definition of the structure of professional training of food industry technologist-students for the use of optimal physical training regimes. Scientific journal of the National Pedagogical University named after M. P. Dragomanov. Series 15: Scientific and Pedagogical Problems of Physical Culture (Physical Culture and Sport), 3 (46), 87-92).

Хоменко, О. С. (2017). Професійно-прикладна фізична підготовка студентів аграрних спеціальностей. Науковий часопис Національного педагогічного університету імені М. П. Драгоманова. Серія 15 : Науково-педагогічні проблеми фрізичної культури (фізична культура і спорт), 4, 123-127. Режим доступу: http://nbuv.gov.ua/UJRN/Nchnpu 0152017435 (Khomenko, O. S. (2017). Professional-applied physical training of students of agrarian specialties. Scientific journal of the National Pedagogical University named after M. $P$. Dragomanov. Series 15: Scientific and Pedagogical Problems of Physical Culture (Physical Culture and Sport), 4, 123-127. Retrieved from: http://nbuv.gov.ua/UJRN/Nchnpu $0152017 \quad 4 \quad 35$ ). 
Karabanov, Y. A. (2015). Professional applied physical training of future specialists of agricultural production. Pedagogics, psychology, medical-biological problems of physical training and sports, 1, 34-39.

\section{PEЗЮME}

Сахненко Анна. Анализ уровня профессионально-прикладной осведомленности студентов аграрных специальностей.

В представленной статье рассмотрена структура профессиональноприкладной физической подготовки студентов высших учебных заведений. Исследован уровень профессионально-прикладной осведомленности студенческой молодежи аграрных специальностей. Установлено, что теоретическая составляющая профрессионально-прикладной физической подготовки значительно влияет на формирование системы теоретических и практических знаний студентов, необходимых будущим специалистам агропромышленного комплекса в профессиональной деятельности и быту.

Анализ анкетных данных позволил констатировать недостаточный уровень знаний будущих специалистов агропромышленного комплекса в области физической культуры, спорта, здорового образа жизни и профессионально-прикладной физической подготовки.

Ключевые слова: профессионально-прикладная осведомленность, физическое воспитание, уровень, компонент, объем знаний, студенты аграрных специальностей.

\section{SUMMARY}

Sakhnenko Anna. Analysis of the level of professional-applied awareness of students of agrarian specialties.

The problem of professional-applied physical training of students of higher education institutions of 3-4 accreditation levels requires detailed elaboration in the modern social economic conditions of Ukraine for optimizing the process of physical education. There is a need for student youth for the formation of a harmoniously developed personality and professional competence of the future specialist of the corresponding profile. One of the main criteria for the effectiveness of physical education of graduates is knowledge of the basics of professional-applied physical training and the ability to apply it in practice.

In conditions of increasing competition on the labor market, the requirements for professional training of specialists are significantly increased, including professional-applied physical training, which is the key to the practical implementation of knowledge and skills in professional activities. Professional-applied physical training in higher education institutions is one of the main tasks of physical education of students: it is intended to equip them with theoretical knowledge, to raise physical and special qualities, to develop motor skills that provide physical and psychological readiness for future professional activity. Therefore, PAPT most significantly embodies one of the most important principles of the pedagogical system the principle of organic connection of physical education with the practice of labour activity.

In the presented article the structure of professional-applied physical training of students of higher education institutions is considered. The level of professional-applied knowledge of student youth of agrarian specialties is studied. It is established that the theoretical component of professional-applied physical training greatly influences formation of the system of theoretical and practical knowledge of students necessary for the future specialists of the agro-industrial complex in professional activity and everyday life. An analysis of personal data has allowed to find out the insufficient level of knowledge of future 
specialists in the agro-industrial complex in the field of physical culture, sports, healthy lifestyle and professional-applied physical training.

Key words: professional-applied knowledge, physical education, level, component, volume of knowledge, students of agrarian specialties.

УДК 796.011.3(073):378.4

Роман Харченко

Сумський національний аграрний університет ORCID ID 0000-0002-7683-5835

Сергій Хоменко

Сумський національний аграрний університет ORCID ID 0000-0002-2105-0432

Андрій Красілов

Сумський державний педагогічний університет імені А. С. Макаренка ORCID ID 0000-0002-7725-5074

Петро Рибалко

Сумський державний педагогічний університет імені А. С. Макаренка ORCID ID 0000-0002-6460-4255

DOI 10.24139/2312-5993/2019.05/183-194

\section{МЕТОДИКА ВИКЛАДАННЯ НАВЧАЛЬНОЇ ДИСЦИПЛІНИ «ФІЗИЧНЕ ВИХОВАННЯ» У ЗАКЛАДІ ВИЩОЇ ОСВІТИ}

Зміст даної статті полягає у створенні і апробації методики, яка дозволяє враховувати особливості студентів у залежності від обсягу спеціальної рухової активності й успішності навчання, суттево підвищуючи продуктивність їх рухових умінь та пізнавальної активності. Розглянуто стан вищої освіти на сучасному етапі розвитку суспільства. По-перше, на фоні загальних змін, які відбуваються з вищою освітою, а, по-друге, з урахуванням особливостей програмного змісту навчання студентів закладу вищої освіти й контингенту студентів.

Ключові слова: студент, фрізичне виховання, навчання, заклад вищої освіти, здоров'я, фрізичні якості.

Постановка проблеми. Стрімкі зміни в умовах сучасного розвитку та Європейський вектор розвитку вимагають суттєвих змін у всіх сферах життя.

Ці зміни не оминули й освіту. Освітній процес у вищій школі пов'язаний із підвищеним інтелектуальним навантаженням і, як наслідок, із домінуванням діяльності центральної нервової системи (найчастіше підвищеної інтенсивності) над життєдіяльністю всіх інших базових систем організму студентської молоді (Закон України «Про фізичну культуру і спорт»). 